\title{
Spatial and Seasonal Variations of Pharmaceuticals and Endocrine Disruptors in the Atibaia River, São Paulo State (Brazil)
}

\author{
Cassiana C. Montagner* and Wilson F. Jardim
}

\author{
Institute of Chemistry, University of Campinas, CP 6154, 13083-970 Campinas-SP, Brazil
}

\begin{abstract}
Um método foi otimizado usando extração em fase sólida (SPE) e cromatografia líquida de alta eficiência (HPLC) com detecção por ultravioleta com arranjo de diodos (UV/DAD) ou fluorescência (FLD) para a determinação de 15 contaminantes emergentes em águas superficiais, a saber: acetoaminofenol, ácido salicílico, diclofenaco, ibuprofeno, cafeína, $17 \beta$-estradiol, estrona, progesterona, $17 \alpha$-etinilestradiol, levonorgestrel, dietilftalato, dibutilftalato, 4-octilfenol, 4-nonilfenol e bisfenol A. Os parâmetros de qualidade do método proposto mostraram a linearidade com $r^{2}>0,996$, coeficiente de variação menor que 5\%, recuperações entre 80 e $120 \%$ para Milli-Q fortificada com $10 \mu \mathrm{g} \mathrm{L}^{-1}$ de cada um dos quinze compostos. O menor limite de detecção (LOD) foi $38 \mathrm{ng} \mathrm{L}^{-1}$ para cafeína e o maior $170 \mathrm{ng} \mathrm{L}^{-1}$ para ibuprofeno. O método foi aplicado para o monitoramento espacial e sazonal destes compostos na bacia do rio Atibaia, principal manancial de abastecimento público da cidade de Campinas-SP, Brasil. Dentre os 15 contaminantes emergentes estudados, 10 foram detectados em pelo menos uma amostra. A menor concentração determinada foi de $0,096 \mu \mathrm{g} \mathrm{L}^{-1}$ para o diclofenaco e a maior foi de $127 \mu \mathrm{g} \mathrm{L} \mathrm{L}^{-1}$ para cafeína.
\end{abstract}

A single run optimization chromatographic method for the determination of 15 emerging contaminants in surface water was optimized using solid-phase extraction (SPE) and high performance liquid chromatography (HPLC) with detection through ultraviolet-diode array (UV-DAD) or fluorescence (FLD). Selected compounds included acetaminophen, acetylsalicylic acid, diclofenac, ibuprofen, caffeine, 17 $\beta$-estradiol, estrone, progesterone, $17 \alpha$-ethynylestradiol, levonorgestrel, diethylphthalate, dibutylphthalate, 4-octylphenol, 4-nonylphenol and bisphenol A. Quality parameters of the proposed method showed a linearity $r^{2}>0.996$, coefficient of variation lower than $5 \%$, recoveries between 80 to $120 \%$ for a spike of $10 \mu \mathrm{g} \mathrm{L}^{-1}$ for each of the 15 compounds. The lowest limit of detection (LOD) was $38 \mathrm{ng} \mathrm{L}^{-1}$ for caffeine, whereas the highest value was $170 \mathrm{ng} \mathrm{L}^{-1}$ for ibuprofen. The method was applied to the spatial and seasonal monitoring of these compounds in the Atibaia River, which is the main drinking water source for Campinas City (São Paulo State, Brazil). Among the 15 selected emerging contaminants, 10 were detected at least once. The lowest concentration determined was $0.096 \mu \mathrm{g} \mathrm{L}^{-1}$ for diclofenac, whereas caffeine showed concentrations as high as $127 \mu \mathrm{g} \mathrm{\textrm {L } ^ { - 1 }}$.

Keywords: pharmaceuticals, endocrine disruptors compounds, solid-phase extraction, liquid chromatography with diode array detection, liquid chromatography with fluorescence detection, Atibaia River Basin

\section{Introduction}

During the last two decades, the scientific community has focused its attention on emerging contaminants such as pharmaceuticals, hormones and personal care products. The alkylphenols, phthalates and bisphenol A contaminants are also of concern and need to be monitored as they are harmful to the aquatic biota. This concern arises from the fact that some substances classified as endocrine disruptors are capable

*e-mail: montagner@iqm.unicamp.br, wfjardim@iqm.unicamp.br of interfering in the endocrine system of animals that are constantly exposed to them. ${ }^{1}$ Little is known about the possible effects they may cause to human health. Some evidence suggests the anticipation of the menarche, ${ }^{2,3}$ the deterioration of semen quality, ${ }^{4}$ and the increase in the incidence of breast cancer ${ }^{5}$ may be associated with the human exposure to these compounds. At present, emerging contaminants like nanomaterials, sun blockers, flame retardants, non-prescription drugs, pharmaceuticals and personal care products are not considered under the current legislation which regulates drinking water quality. However, di(2-ethylhexyl) phthalate 
(DEHP) and some surfactants such as octylphenols and nonylphenols have already being included in the list of priority substances by the European Water Framework Directive, ${ }^{6}$ and bisphenol A is monitored but not regulated by the U.S. Food and Drug Administration. ${ }^{7}$ Caffeine is one the most consumed substances in the world and its presence in surface waters is a clear indicator of anthropogenic influence. ${ }^{8}$

Most of these contaminants are organic compounds belonging to different classes and, therefore, presents quite different physicochemical characteristics. Some of them are very recalcitrant which hinders their complete degradation when passing through the water treatment system. ${ }^{9}$ Numerous studies have demonstrated that wastewaters are the major contributors to the contamination of the water bodies by these substances. ${ }^{10-12}$ This occurs because the conventional wastewater treatment plants are not efficiently able to remove some of these compounds. Moreover, in some areas of Brazil, for example, the discharges of raw sewage into rivers and lakes are widely practiced. Emerging technologies showing higher efficiency in removing these pollutants are now applied in water treatment plants in several countries concerned with the quality of their watersheds and the drinking water derived from them. ${ }^{9,13-16}$

In Brazil, little is known about the presence of those compounds in its water bodies. In the southeastern area of the country, with a high population density, the quality of the rivers and reservoirs supplying the population is quite impaired due to the poor sanitary situation, where only $33 \%$ of sewage receives adequate treatment before being released into receiving waters. ${ }^{17}$
This work reports the optimization of a single run chromatographic method to quantify 15 emerging contaminants in surface waters. The developed procedure was used to assess spatial and seasonal variations of some selected contaminants in the Atibaia River, which is the major water supply of the Campinas Metropolitan Area in São Paulo State, Brazil. The proposed method uses solid-phase extraction (SPE) followed by high performance liquid chromatography (HPLC) using ultraviolet-diode array (UV-DAD) and fluorescence (FLD) detection. The targeted compounds were five pharmaceuticals (acetaminophen, acetylsalicylic acid, diclofenac, ibuprofen and caffeine) and ten organic compounds classified as endocrine disruptors from different classes, such as natural hormones (17 $\beta$-estradiol, estrone and progesterone), synthetic hormones (17 $\alpha$-ethynylestradiol and levonorgestrel), phthalate esters (diethylphthalate and dibutylphthalate), surfactants (4-nonylphenol and 4-octylphenol) and bisphenol A. Table 1 shows some physicochemical characteristics of the selected compounds.

\section{Experimental}

\section{Sampling sites}

Eight sampling sites were selected in the Atibaia River Basin, being six along the Atibaia River, one at the Anhumas Creek and one at the Pinheiros Creek, both tributaries to that body of water, and receiving high load of sewerage along their courses. Figure 1 displays the location of the eight sampling sites.

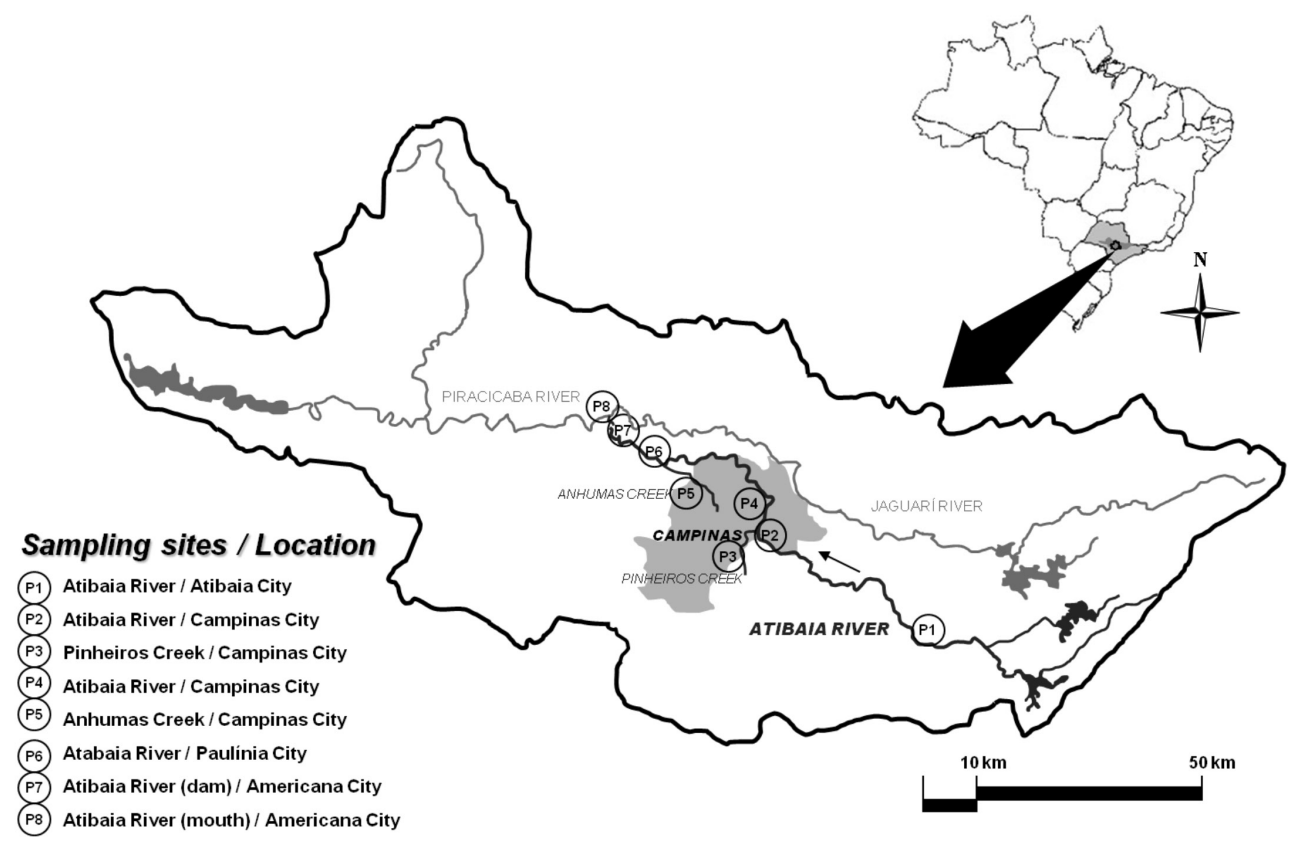

Figure 1. Map of the study area and location of the sampling sites. 
Table 1. Physicochemical properties of the compounds screened in surface waters

\begin{tabular}{|c|c|c|c|c|c|c|c|}
\hline Compound & CAS No. & Chemical structure & $\begin{array}{l}\text { Molecular } \\
\text { formula }\end{array}$ & $\begin{array}{c}\text { Molar mass / } \\
\left(\mathrm{g} \mathrm{mol}^{-1}\right)\end{array}$ & $\mathrm{pK}_{\mathrm{a}}$ & $\log \mathrm{K}_{\mathrm{ow}}$ & $\begin{array}{c}\text { 申sat } 25^{\circ} \mathrm{C} / \\
\left(\mathrm{mg} \mathrm{L}^{-1}\right)\end{array}$ \\
\hline Acetylsalicylic acid (AAS) & $50-78-2$ & & $\mathrm{C}_{9} \mathrm{H}_{8} \mathrm{O}_{4}$ & 180.16 & $2.9^{18}$ & $2.3^{18}$ & $3,333^{19}$ \\
\hline Acetaminophen & $103-90-2$ & & $\mathrm{C}_{8} \mathrm{H}_{9} \mathrm{NO}_{2}$ & 151.17 & $9.4^{20}$ & $0.46^{20}$ & - \\
\hline Caffeine & $58-08-2$ & & $\mathrm{C}_{8} \mathrm{H}_{10} \mathrm{~N}_{4} \mathrm{O}_{2}$ & 194.19 & $10.4^{9}$ & $0.01^{21}$ & $21,700^{19}$ \\
\hline Diclofenac & $15307-79-6$ & & $\mathrm{C}_{14} \mathrm{H}_{11} \mathrm{C}_{12} \mathrm{NO}_{2}$ & 296.15 & $4.2^{18}$ & $4.5^{18}$ & $2.4^{22}$ \\
\hline Ibuprofen & $15687-27-1$ & & $\mathrm{C}_{13} \mathrm{H}_{18} \mathrm{O}_{2}$ & 206.28 & $4.9^{18}$ & $3.97^{18}$ & $21^{22}$ \\
\hline $17 \alpha$-Ethynylestradiol & $57-63-6$ & & $\mathrm{C}_{20} \mathrm{H}_{24} \mathrm{O}_{2}$ & 296.41 & $10.4^{9}$ & $3.7^{23}$ & $4.8^{24,25}$ \\
\hline Levonorgestrel & $797-63-7$ & & $\mathrm{C}_{21} \mathrm{H}_{28} \mathrm{O}_{2}$ & 312.45 & - & - & $2.1^{25}$ \\
\hline $17 \beta$-Estradiol & $50-28-2$ & & $\mathrm{C}_{18} \mathrm{H}_{24} \mathrm{O}_{2}$ & 272.39 & $10.4^{9}$ & $4.0^{23}$ & $13^{24}$ \\
\hline Estrone & $53-16-7$ & & $\mathrm{C}_{18} \mathrm{H}_{22} \mathrm{O}_{2}$ & 270.37 & $10.4^{9}$ & $3.1^{23}$ & $30^{19}$ \\
\hline Progesterone & $57-83-0$ & & $\mathrm{C}_{21} \mathrm{H}_{30} \mathrm{O}_{2}$ & 314.47 & - & $3.9^{23}$ & $8.8^{26}$ \\
\hline Bisphenol A & $80-05-7$ & & $\mathrm{C}_{15} \mathrm{H}_{16} \mathrm{O}_{2}$ & 228.29 & $10.2^{20}$ & $3.3^{23}$ & $120^{27}$ \\
\hline 4-Octylphenol & $84-66-2$ & & $\mathrm{C}_{14} \mathrm{H}_{22} \mathrm{O}$ & 206.32 & - & $4.1^{26}$ & $5.0^{27}$ \\
\hline 4-Nonylphenol & $104-40-5$ & & $\mathrm{C}_{15} \mathrm{H}_{24} \mathrm{O}$ & 220.35 & $10.3^{19}$ & $4.5^{23}$ & $7.0^{24}$ \\
\hline Diethylphthalate & $1806-26-4$ & & $\mathrm{C}_{12} \mathrm{H}_{14} \mathrm{O}_{4}$ & 222.24 & - & $3.2^{23}$ & $400^{27}$ \\
\hline Dibutylphthalate & $84-74-2$ & & $\mathrm{C}_{16} \mathrm{H}_{22} \mathrm{O}_{4}$ & 278.35 & - & $4.57^{27}$ & $11.2^{27}$ \\
\hline
\end{tabular}


The Atibaia River basin located in São Paulo State (Brazil), covers an area of approximately $2,800 \mathrm{~km}^{2}$ (Figure 1). Basically, its source is in the Camanducaia District, Minas Gerais State, flowing to west of São Paulo State. P1, P2, P4, P6, P7 and P8 sampling sites were located in the Atibaia River. P1 site was located at the water intake station in Atibaia City and supplies approximately 100,000 inhabitants. P2 site was located on the Atibaia River $200 \mathrm{~m}$ upstream from the mouth of Pinheiros Creek. The P4 site was located 1,600 m dowstream P2 site, at water intake treatment plant in Campinas, which provides drinking water to nearly 1 million people. The P6 sampling point was located close to the Paulínia City, near to an industrial park. Both P7 and P8 points were located further on Atibaia River downstream, close to Americana City. The P7 point refers to the Salto Grande Dam, and P8 site was located approximately $200 \mathrm{~m}$ before the Atibaia River jointing to the Jaguari River to form the Piracicaba River. P3 sampling point refers to the Pinheiros Creek, approximately $100 \mathrm{~m}$ before its entrance into the Atibaia River. Finally, P5 point refers to the Anhumas Creek, upstream from its entrance into the Atibaia River, and immediately downstream from Campinas, where $45 \%$ of the domestic sewerage load is discharged.

Four sampling campaigns were carried out in order to determine variations in the concentration of these compounds in the watershed. Two sampling campaigns were carried out during high rainy periods in early March 2006 and in January 2007. The other two were done during the dry winter period, in May and July 2006. Rain precipitation data on a daily basis during the period between January 2006 and February 2007 were provided by the CEPAGRI - Centro de Pesquisas Meteorológicas e Climáticas Aplicadas à Agricultura ${ }^{28}$ (Meteorological Center of Climatic Research Applied to the Agriculture) of University of Campinas.

\section{Analytical methods}

\section{Chemicals and materials}

Reference standard reagents (purity > 97\%) were purchased from Sigma-Aldrich (Steinheim, Germany), except 4-nonylphenol, which was acquired from Riedelde Haën (Seelze, Germany). Individual $500 \mathrm{mg} \mathrm{L}^{-1}$ stock solutions were prepared by dissolving appropriate amount of standard in nanograde methanol (Mallinckrodt, Phillipsburg, USA) and kept at $4{ }^{\circ} \mathrm{C}$. Reference solutions in the range of 0.005 to $10 \mathrm{mg} \mathrm{L}^{-1}$ were prepared in HPLC-grade acetonitrile (JT Baker, Xalostoc, Mexico) from appropriate dilutions of the stock solutions. Hydrochloric acid (JT Baker) was used for sample preservation and to prepare the mobile phase. Acetone (Tedia, Fairfield NJ, USA) was used for cleaning the glassware. Distilled water was further purified in an ultrapure Milli-Q system (resistivity of $18.2 \mathrm{M} \Omega \mathrm{cm}$ ).

\section{Sampling}

Amber glass bottles used to collect the water samples were rinsed with detergent solution, then with tap water, rinsed again with distilled water, then ethanol and finally acetone. After this treatment, the glass bottles were heated at $400{ }^{\circ} \mathrm{C}$ for $4 \mathrm{~h}$ and capped with aluminum foil.

Volumes of $4 \mathrm{~L}$ of surface water were collected in each sampling site using an amber glass bottle, sealed and transported in thermal boxes to the laboratory, and immediately analyzed for total organic carbon (TOC) using a TOC-V CPN from Shimadzu. In the fourth sampling campaign, performed during the rainy season, temperature, $\mathrm{pH}$, conductivity and dissolved oxygen were measured. The measurements were accomplished in situ using a 340i/ SET-WTW multi parameter meter.

\section{Sample preparation}

A volume of $1 \mathrm{~L}$ of sample was vacuum filtered in a closed glass system using a $0.45 \mu \mathrm{m}$ cellulose acetate membrane (Advanted MFS, Pleasanton, CA, USA). Filtered water samples were acidified to $c a$. $\mathrm{pH} 3$ using a $5 \mathrm{~mol} \mathrm{~L}^{-1}$ $\mathrm{HCl}$ solution. Extraction of the selected compounds was performed with a PrepSep 12-port vacuum manifold (Fisher Scientific, Pittsburgh, PA, USA) using hydrophiliclipophilic balance HLB OASIS 500-mg (Waters, Milford, MA, USA). The cartridges were previously conditioned with $6 \mathrm{~mL}$ methanol, $6 \mathrm{~mL}$ water and $6 \mathrm{~mL}$ of acidified water (ca. pH 3). Extractions were performed at a flow rate of $10 \mathrm{~mL} \mathrm{~min}^{-1}$, followed by elution with $4 \times 3 \mathrm{~mL}$ of methanol. The eluate was concentrated until dryness with purified nitrogen and reconstituted with $0.5 \mathrm{~mL}$ of acetonitrile, yielding a concentration factor of 2,000 times. Final extracts were kept at $4{ }^{\circ} \mathrm{C}$ until the chromatographic determinations (within $72 \mathrm{~h}$ ).

\section{Chemical determination}

The chromatographic separation was performed in a SCL 10AVP Shimadzu (Shimadzu Corporation, Kyoto, Japan) HPLC equipped with a Shim-pack G-ODS(4) 4 mm internal diameter guard column and a Capcell Pack C18 AG120 S-5 (Shiseido Co) $250 \mathrm{~mm}$ long $4.6 \mathrm{~mm}$ internal diameter separation column. The acetonitrile and the water used in the mobile phase were previously degassed before pumping by a LC 10A DVP station. Two detectors were used in this procedure: a SPD-M10VP (Shimadzu Corporation, Kyoto, Japan) ultraviolet diode array detector and a RF-10A XL (Shimadzu Corporation, Kyoto, Japan) molecular fluorescence detector. 
A binary gradient consisting of acidified water and acetonitrile at a flow rate of $0.8 \mathrm{~mL} \mathrm{~min}{ }^{-1}$ was used the elution gradient started with $10 \%$ acetonitrile, with linear increase until $90 \%$ for $30 \mathrm{~min}$ and up to $92 \%$ in $5 \mathrm{~min}$, finally reaching $95 \%$ in $2 \mathrm{~min}$. Initial conditions were achieved and equilibrated in $3 \mathrm{~min}$. Total run time was $40 \mathrm{~min}$ and $20 \mu \mathrm{L}$ were injected. A simplified flowchart of the analytical procedure is shown in Figure 2.

Quantitative determination was achieved with diode array detection at $280 \mathrm{~nm}$ for acetylsalicylic acid, diclofenac, ibuprofen, caffeine, estrone, diethylphthalate, dibutylphthalate, 4-octylphenol and 4-nonylphenol. For acetaminophen, progesterone and levonorgestrel, the wavelength used was $240 \mathrm{~nm}$. Fluorescence detection was used to quantify $17 \beta$-estradiol, $17 \alpha$-ethynylestradiol and bisphenol A, fixing the excitation wavelength $\left(\lambda_{\text {excitation }}\right)$ at $230 \mathrm{~nm}$ and the emission wavelength $\left(\lambda_{\text {emission }}\right)$ at $310 \mathrm{~nm}$.

The method performance was evaluated through the following quality parameters: linearity, detectability, precision and recovery, and compared to the quality control proposed for Method 1694 and Method 1698 of the United States Environmental Protection Agency (USEPA). ${ }^{29,30}$

The quantification was carried out using external standard calibration, therefore the matrix effect was not considered when obtaining the parameters of the method. The limit of detection $\left(L O D=\frac{3 s_{a}}{b}\right)$ and the limit of quantification $\left(L O Q=\frac{10 s_{a}}{b}\right)$ were determined statistically in the $50-1,000 \mu \mathrm{g} \mathrm{L}-1$ linear range, where $S_{a}$ is the estimate of standard deviation in the intercept with the $y$ axis of at least three calibration curves and $b$ is the slope of the analytical curve. ${ }^{31}$

The detectability of the proposed procedure was evaluated by comparing three chromatograms: the first one of a river water sample, the second one of this same river water spiked at $1.0 \mu \mathrm{g} \mathrm{L}^{-1}$ and the third one a Milli-Q water sample spiked at $1.0 \mu \mathrm{g} \mathrm{L}^{-1}$. A Milli-Q water blank was also analyzed to check for possible cross-contamination in the laboratory.

The precision of the method was evaluated by calculating the estimated absolute standard deviation (s) and the coefficient of variation (CV) for six replicates. Recoveries (\%) were calculated after spiking in Milli-Q water with amounts of the selected compounds at two levels, 1.0 and $10.0 \mu \mathrm{g} \mathrm{L}^{-1}$.

\section{Results and Discussion}

\section{The method}

The optimized gradient program used in the chromatographic analysis provided a suitable separation

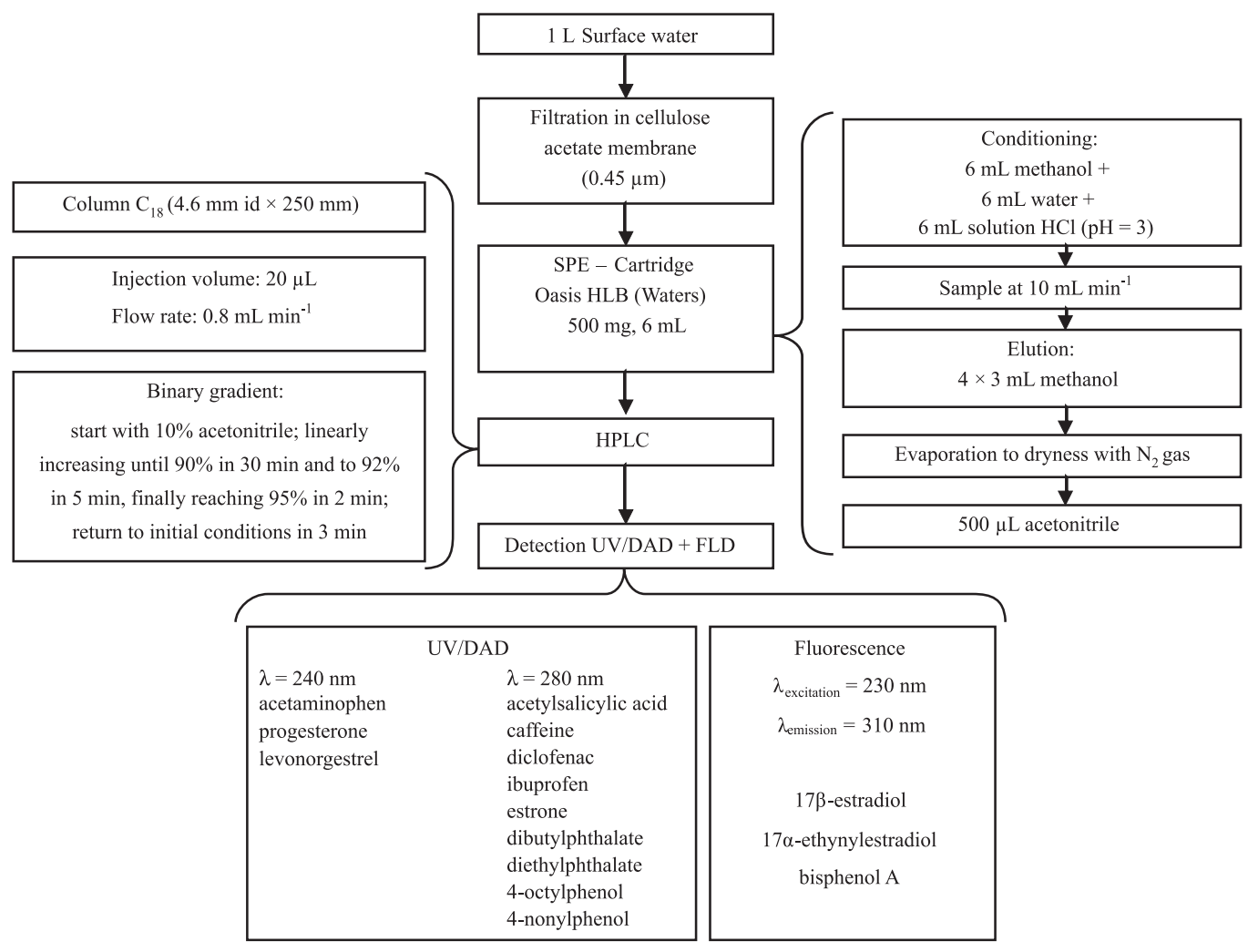

Figure 2. Schematic diagram of the analytical procedure used for determination of the pharmaceuticals and endocrine disruptors studied in this work. 
Table 2. Retention times $\left(t_{R}\right)$, maximum wavelengths $\left(\lambda_{\max }\right)$, linearities, limits of detection (LOD) and quantification (LOQ) and recoveries (\%) for the 15 target compounds

\begin{tabular}{|c|c|c|c|c|c|c|c|}
\hline \multirow{2}{*}{ Compounds } & \multirow{2}{*}{$t_{R} / \min$} & \multirow{2}{*}{$\lambda_{\max } / \mathrm{nm}$} & \multirow{2}{*}{ Linearity } & \multirow{2}{*}{$\mathrm{LOD} /\left(\mathrm{ng} \mathrm{L}^{-1}\right)$} & \multirow{2}{*}{ LOQ / (ng L-1) } & \multicolumn{2}{|c|}{ Recovery / \% } \\
\hline & & & & & & $1.0 \mu \mathrm{g} \mathrm{L}^{-1}$ & $10.0 \mu \mathrm{g} \mathrm{L}^{-1}$ \\
\hline Acetylsalicylic acid & 15.8 & 301 & 0.997 & 49 & 164 & 50 & 108 \\
\hline Acetaminophen & 8.4 & 244 & 0.997 & 34 & 112 & 51 & 84 \\
\hline Caffeine & 10.2 & 272 & 0.998 & 11 & 38 & 74 & 102 \\
\hline Diclofenac & 26.1 & 274 & 0.999 & 14 & 46 & 65 & 101 \\
\hline Ibuprofen & 26.7 & 263 & 0.997 & 51 & 170 & 68 & 108 \\
\hline $17 \alpha$-Ethynylestradiol* & 23.2 & & 0.999 & 17 & 56 & 74 & 108 \\
\hline Levonorgestrel & 25.3 & 241 & 0.998 & 19 & 63 & 72 & 92 \\
\hline $17 \beta$-Estradiol* & 22.1 & & 0.999 & 45 & 152 & 65 & 109 \\
\hline Estrone & 23.8 & 280 & 0.999 & 16 & 55 & 50 & 72 \\
\hline Progesterone & 28.7 & 241 & 0.996 & 12 & 66 & 68 & 96 \\
\hline Bisphenol A* & 21.5 & & 0.998 & 38 & 128 & 85 & 97 \\
\hline 4-Octylphenol & 34.1 & 278 & 0.997 & 21 & 70 & 58 & 81 \\
\hline 4-Nonylphenol & 35.9 & 278 & 0.997 & 18 & 59 & 57 & 80 \\
\hline Diethylphthalate & 24.3 & 274 & 0.999 & 33 & 110 & 73 & 89 \\
\hline Dibutylphthalate & 32.1 & 273 & 0.997 & 29 & 96 & 98 & 120 \\
\hline
\end{tabular}

* Determined by fluorescence detector.

of the 15 selected compounds in a single run. Table 2 shows the retention times, maximum wavelengths used to confirm each of the 15 selected compounds, and some quality parameters of the method, such as linearity, limits of detection (LOD) and quantification (LOQ), and recoveries at both levels of concentration used.

The method developed exhibits excellent linearity for all compounds in the range 50-1,000 $\mu \mathrm{g} \mathrm{\textrm {L } ^ { - 1 }}\left(\mathrm{r}^{2}>0.996\right)$. As expected, LOD and LOQ were different for each of the fifteen compounds. The lowest LOD and LOQ values were obtained for caffeine (11 and $38 \mathrm{ng} \mathrm{L}^{-1}$, respectively) whereas the highest values were 51 and $170 \mathrm{ng} \mathrm{L}^{-1}$ for ibuprofen, respectively.

Higher recoveries, evaluated by the efficiency of the solid-phase extraction, were obtained with more concentrated samples. For a Milli-Q water sample containing $1.0 \mu \mathrm{g} \mathrm{L}^{-1}$, recoveries from 50 to $98 \%$ were obtained, while values of 80 to $120 \%$ were obtained for all the compounds present in a Milli-Q water sample spiked at $10 \mu \mathrm{g} \mathrm{L}{ }^{-1}$. These values of recovery are satisfactory when dealing with complex environmental samples like the ones analyzed in this work. The variations in the extraction efficiencies can be attributed to the distinct chemical properties of the substances, which undergo different interactions with the sorbent in the extraction process.

Alda and Barceló, ${ }^{32-34}$ using HPLC-DAD, obtained recoveries from 78 to $101 \%$ for hormones found in water samples at concentrations at least 100 times higher than the ones used in the present work, while the detection limits were similar (from 10 to $50 \mathrm{ng} \mathrm{L}^{-1}$ ). With respect to the pharmaceuticals, Santos et al. ${ }^{35}$ under the same experimental conditions used in this procedure, obtained average recoveries between 78 and $89 \%$, with LOD values from 70 to $960 \mathrm{ng} \mathrm{L}^{-1}$ and LOQ values from 220 to $3,200 \mathrm{ng} \mathrm{L}^{-1}$, which are higher values compared with the ones from the present method. Chen et al. ${ }^{8}$ determined caffeine in natural waters using SPE-HPLC-DAD with a detection limit of $100 \mathrm{ng} \mathrm{L}^{-1}$ for a $50 \mathrm{~mL}$ synthetic sample. Ribeiro et al. ${ }^{36}$ developed a SPE-HPLC-DAD method for the determination of nine endocrine disruptors, including hormones, bisphenol A and alkylphenols in river water samples, with recoveries of $116 \%$ for a $1.0 \mu \mathrm{g} \mathrm{L}^{-1}$ synthetic sample, a coefficient of variation of $3.0 \%$ and LOQ values between 12 and $54 \mathrm{ng} \mathrm{L}^{-1}$.

The detection limit values depend on both the type of detector used and the concentration factor provided by the solid-phase extraction step. Thus, more complex matrices, such as river and lake water samples, as well as sewage, dictate the sample volume for extraction and, consequently, the values of LOD and LOQ. In the present work, LOD values ranged from 11 to $51 \mathrm{ng} \mathrm{L}^{-1}$, for a $1 \mathrm{~L}$ sample extraction, which means a concentration factor of 2,000 times.

The detectability, defined as the method ability to distinguish compounds of interest from other components such as interfering substances, degradation products and 
matrix components, was evaluated by comparing the three chromatograms shown in Figure 3. It can be noted that the proposed method was selective for all of the compounds investigated. Acetaminophen, caffeine, bisphenol A and dibutylphthalate were found above the respective limits of detection in the Atibaia River water samples. To improve selective, quantitative determinations were performed at different wavelengths for each group of compounds ( 240 e $280 \mathrm{~nm}$ ).

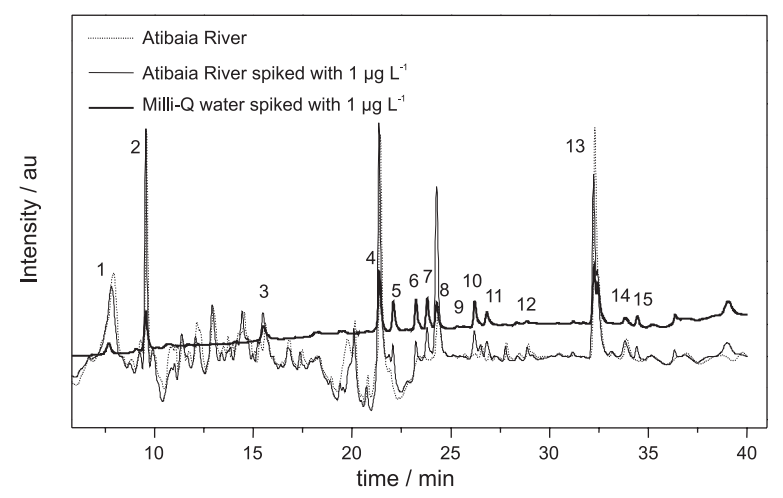

Figure 3. Chromatograms obtained in HPLC-DAD at $280 \mathrm{~nm}$ of $(i)$ water sample from Atibaia River, (ii) water sample from Atibaia River spiked with $1.0 \mu \mathrm{g} \mathrm{L} \mathrm{L}^{-1}$ level with the 15 selected compounds and (iii) Milli-Q sample spiked with the $1.0 \mu \mathrm{g} \mathrm{L}^{-1}$ level with the 15 selected compounds (1: acetaminophen, 2: caffeine, 3: acetylsalicilic acid, 4: bisphenol A, 5: 17ß-estradiol, 6: 17 $\alpha$-ethynylestradiol, 7: estrone, 8: diethylphtalate, 9: levonorgestrel, 10: diclofenac, 11: ibuprofen, 12: progesterone, 13: dibutylphthalate, 14: 4-octylphenol and 15: 4-nonylphenol).

The confirmation of the compounds was performed based on the UV absorption spectra which are characteristic for each compound under study. The spectra obtained for each of the 15 compounds of interest in the standard solution were compared to the ones obtained in the river water samples in order to confirm the presence of these compounds in the natural water samples.

The precision of the proposed method was calculated through intra-day and inter-day repeatability. The first represents the agreement between the results of six successive measurements, performed by the same analyst, under the same conditions of analysis, with the same instrument at the same location and on the same day, with a time interval of few hours (Figure 4a). The second represents the agreement among the results of ten successive measurements, carried out by the same analyst, under the same conditions, with the same instrument, but on three different days (Figure 4b). Coefficients of variations (CV) were lower than $5 \%$ for 12 of the 15 compounds, being close to $15 \%$ only for dibutylphthalate, 4-octylphenol and 4-nonylphenol. In USEPA Method 1698, ${ }^{29,30}$ maximum recommended CV values are $20 \%$ for river water samples.
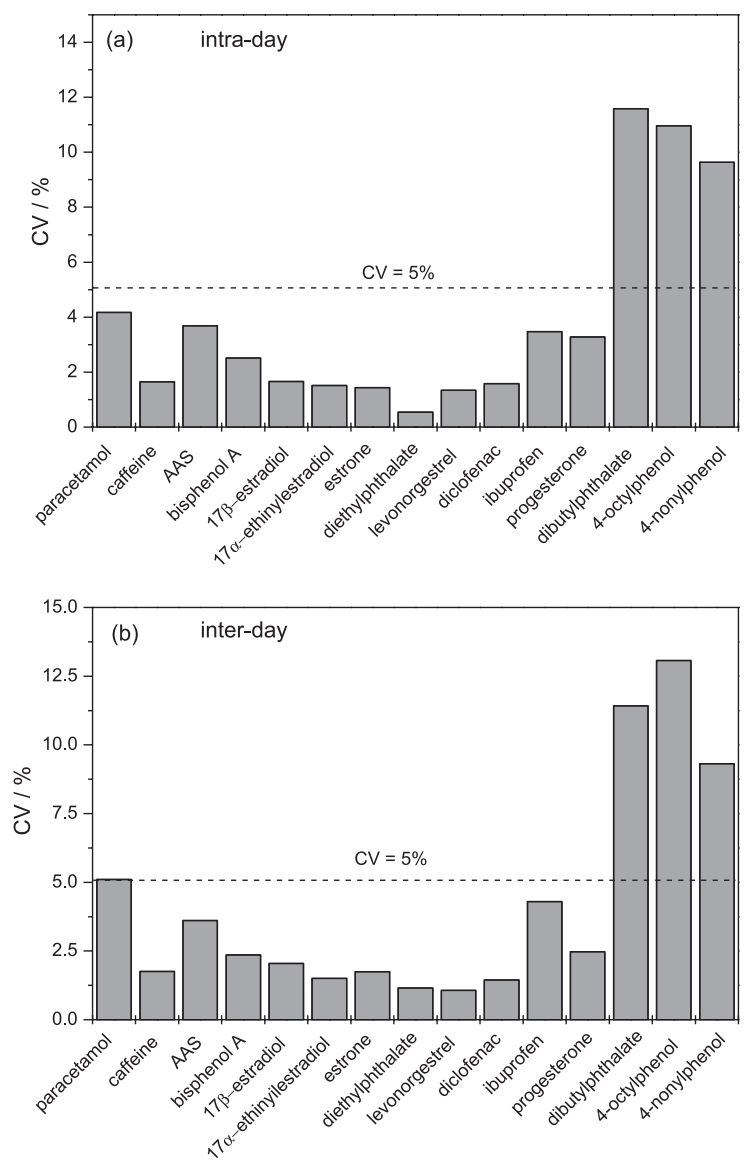

Figure 4. Coefficients of variation (CV) values for synthetic samples contained $1.0 \mu \mathrm{g} \mathrm{L}^{-1}$ of each selected compound (a) intra-day precision: six repetitions in the same day and (b) inter-day precision: ten repetitions in three different days.

\section{Environmental samples}

Table 3 shows the location of the collecttions sites and some physicochemical parameters of the samples. In the high rainfall period, the temperature of the water bodies oscillated between 22.4 and $25.5^{\circ} \mathrm{C}$, the $\mathrm{pH}$ varied between 6.7 and 7.5. The largest conductivity value was obtained for the Pinheiros Creek sample $\left(241 \mu \mathrm{S} \mathrm{cm}^{-1}\right)$, followed by the Atibaia River in Paulínia $\left(225 \mu \mathrm{S} \mathrm{cm}^{-1}\right)$. The other samples presented conductivity between 61 and $126 \mu \mathrm{S} \mathrm{cm}^{-1}$, and the lowest values were detected in the samples collected upstream in Campinas, at P1, P2 and P4 points. The dissolved oxygen varied significantly among the samples from $1.9 \mathrm{mg} \mathrm{L}^{-1}$ for the Anhumas Creek up to $7.0 \mathrm{mg} \mathrm{L}^{-1}$ for the $\mathrm{P} 2$ sampling site in the Atibaia River upstream in Campinas.

The Atibaia River, along its course, presented variation in the dissolved oxygen concentration between 5.4 and $7.0 \mathrm{mg} \mathrm{L}^{-1}$ of $\mathrm{O}_{2}$ from Atibaia (P1 site) downstream to Paulínia (P6 site). However, in Americana, values around $3 \mathrm{mg} \mathrm{L}^{-1}$ of dissolved $\mathrm{O}_{2}$ in the two collection sites were 
Table 3. Location of the collecting sites and some physicochemical parameters of the samples

\begin{tabular}{|c|c|c|c|c|c|c|c|c|c|c|c|}
\hline \multirow[b]{2}{*}{ Sample } & \multirow[b]{2}{*}{ Water bodies / location } & \multirow[b]{2}{*}{ Latitude } & \multirow[b]{2}{*}{ Longitude } & \multirow[b]{2}{*}{$\mathrm{T} /{ }^{\circ} \mathrm{C}^{\mathrm{a}}$} & \multirow[b]{2}{*}{$\mathrm{pH}^{\mathrm{a}}$} & \multirow{2}{*}{$\begin{array}{c}\text { Conductivity / } \\
\left(\mu \mathrm{S} \mathrm{cm}^{-1}\right)^{\mathrm{a}}\end{array}$} & \multirow{2}{*}{$\begin{array}{c}\mathrm{O}_{2} / \\
\left(\mathrm{mg} \mathrm{L}^{-1}\right)^{\mathrm{a}}\end{array}$} & \multicolumn{4}{|c|}{$\mathrm{TOC} /\left(\mathrm{mg} \mathrm{C} \mathrm{L}^{-1}\right)$} \\
\hline & & & & & & & & $\begin{array}{c}1^{\text {st }} \text { sampling } \\
\text { Mar/06 }\end{array}$ & $\begin{array}{c}2^{\text {nd }} \text { sampling } \\
\text { Jun/06 }\end{array}$ & $\begin{array}{c}3^{\text {rd }} \text { sampling } \\
\text { Aug/06 }\end{array}$ & $\begin{array}{c}4^{\text {th }} \text { sampling } \\
\text { Jan/07 }\end{array}$ \\
\hline \multicolumn{12}{|c|}{ upstream } \\
\hline P1 & Atibaia River / Atibaia City & $23^{\circ} 06^{\prime} 14^{\prime \prime}$ & $46^{\circ} 32^{\prime} 44^{\prime \prime}$ & 22.4 & 6.7 & 61 & 5.4 & 5.4 & 2.7 & 3.0 & 5.7 \\
\hline P2 & Atibaia River / Campinas City & $22^{\circ} 54^{\prime} 39^{\prime \prime}$ & $46^{\circ} 57^{\prime} 22^{\prime \prime}$ & 24.4 & 7.4 & 79 & 7.0 & - & 4.9 & 3.4 & 5.5 \\
\hline P3 & Pinheiros Creek & $22^{\circ} 54^{\prime} 45^{\prime \prime}$ & $46^{\circ} 57^{\prime} 37^{\prime \prime}$ & 22.9 & 7.2 & 241 & 2.9 & - & 21.3 & 6.6 & 5.9 \\
\hline P4 & Atibaia River / Campinas City & $22^{\circ} 54^{\prime} 17^{\prime \prime}$ & $46^{\circ} 58^{\prime} 30^{\prime \prime}$ & 24.1 & 7.4 & 91 & 5.8 & 4.5 & 5.7 & 3.1 & 5.6 \\
\hline P5 & Anhumas Creek & $22^{\circ} 46^{\prime} 10^{\prime \prime}$ & $47^{\circ} 05^{\prime} 42^{\prime \prime}$ & 23.1 & 7.1 & 133 & 1.9 & 7.7 & 43.6 & 13.8 & 10.2 \\
\hline P6 & Atibaia River / Paulínia City & $22^{\circ} 44^{\prime} 44^{\prime \prime}$ & $47^{\circ} 09^{\prime} 34^{\prime \prime}$ & 23.7 & 7.5 & 225 & 5.8 & 6.7 & 3.5 & 3.6 & 6.4 \\
\hline P7 & Atibaia Dam / Americana City & $22^{\circ} 43^{\prime} 14^{\prime \prime}$ & $47^{\circ} 16^{\prime} 24^{\prime \prime}$ & 25.5 & 7.3 & 126 & 3.1 & - & - & 9.1 & 5.8 \\
\hline $\begin{array}{l}\text { P8 } \\
\text { downst }\end{array}$ & Atibaia River / Mouth & $22^{\circ} 41^{\prime} 54^{\prime \prime}$ & $47^{\circ} 17^{\prime} 27^{\prime \prime}$ & 25.4 & 7.2 & 125 & 3.0 & - & - & 4.1 & 6.5 \\
\hline
\end{tabular}

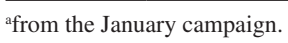

obtained. The decrease in the water quality can also be verified by the increase in the conductivity measured for samples collected downstream from Campinas. Total organic carbon from all four sampling campaigns showed higher concentrations in the Anhumas Creek (between 7.7 and $43.6 \mathrm{mg} \mathrm{C} \mathrm{L}^{-1}$ ), whereas for the other samples TOC varied between 2.7 and $9.1 \mathrm{mg} \mathrm{C} \mathrm{L}^{-1}$.

Table 4 presents the average concentrations and standard deviation obtained in the four campaigns for the fifteen target compounds studied. Figure 5 presents the rainfall in the studied basin along the year of 2006 and the dates of the sampling campaigns.

Caffeine is considered one of the primary indicators of anthropogenic contributions in natural aquatic systems.

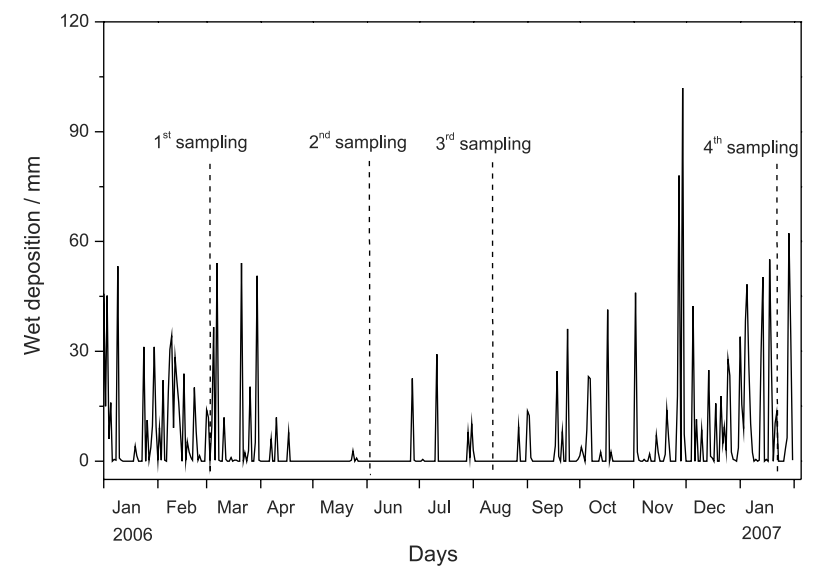

Figure 5. Wet deposition in the watershed and dates of the sampling campaigns.

Table 4. Concentrations of 15 target compounds in the Atibaia River watershed

\begin{tabular}{|c|c|c|c|c|c|c|c|c|c|c|c|c|}
\hline \multirow{3}{*}{ Contaminants } & \multicolumn{12}{|c|}{ Concentration / $\left(\mathrm{ng} \mathrm{L}^{-1}\right)$} \\
\hline & \multicolumn{3}{|c|}{$1^{\text {st }}$ campaign $(n=6)$} & \multicolumn{3}{|c|}{$2^{\text {nd }}$ campaign $(\mathrm{n}=8)$} & \multicolumn{3}{|c|}{$3^{\text {rd }}$ campaign $(n=10)$} & \multicolumn{3}{|c|}{$4^{\text {th }}$ campaign $(n=10)$} \\
\hline & Mean & Range & $\mathrm{x} / \mathrm{n} *$ & Mean & Range & $\mathrm{x} / \mathrm{n} *$ & Mean & Range & $\mathrm{x} / \mathrm{n} *$ & Mean & Range & $\mathrm{x} / \mathrm{n} *$ \\
\hline Acetaminophen & $<34$ & & $0 / 4$ & 13,440 & & $1 / 6$ & 280 & & $1 / 8$ & $<34$ & & $0 / 8$ \\
\hline Acetyl salicylic acid & 476 & & $1 / 4$ & 20,960 & & $1 / 6$ & 12,212 & & $1 / 8$ & $828 \pm 295$ & $(619-1,036)$ & $2 / 8$ \\
\hline Caffeine & $1,170 \pm 1,490$ & $(174-3,343)$ & $4 / 4$ & $25,775 \pm 41,590$ & $(3,339-127,092)$ & $6 / 6$ & $11,565 \pm 25,260$ & $(700-73,900)$ & $8 / 8$ & $2,100 \pm 2,527$ & $(337-5,862)$ & $6 / 8$ \\
\hline Diclofenac & $<14$ & & $0 / 4$ & $<14$ & & $0 / 6$ & $<14$ & & $0 / 8$ & $106 \pm 13$ & $(96-115)$ & $2 / 8$ \\
\hline Ibuprofen & $<51$ & & $0 / 4$ & $<51$ & & $0 / 6$ & $<51$ & & $0 / 8$ & $<51$ & & $0 / 8$ \\
\hline $17 \alpha$-Ethynylestradiol & 981 & & $1 / 4$ & 4,390 & & $1 / 6$ & $<17$ & & $0 / 8$ & 501 & & $1 / 8$ \\
\hline Levonorgestrel & $<19$ & & $0 / 4$ & $<19$ & & $0 / 6$ & $<19$ & & $0 / 8$ & 663 & & $1 / 8$ \\
\hline 17ק-Estradiol & 464 & & $1 / 4$ & 6,806 & & $1 / 6$ & 2,273 & & $1 / 8$ & $523 \pm 538$ & $(106-1,313)$ & $4 / 8$ \\
\hline Estrone & $<16$ & & $0 / 4$ & $<16$ & & $0 / 6$ & $<16$ & & $0 / 8$ & $<16$ & & $0 / 8$ \\
\hline Progesterone & $<20$ & & $0 / 4$ & $<20$ & & $0 / 6$ & $<20$ & & $0 / 8$ & 195 & & $1 / 8$ \\
\hline Bisphenol A & $520 \pm 408$ & (231-808) & $3 / 4$ & $5,394 \pm 5,380$ & $(844-11,725)$ & $5 / 6$ & $6,375 \pm 2,325$ & $(1,889-10,518)$ & $3 / 8$ & $4,617 \pm 7,277$ & $(204-13,016)$ & $3 / 8$ \\
\hline 4-Octylphenol & $<21$ & & $0 / 4$ & $<21$ & & $0 / 6$ & $<21$ & & $0 / 8$ & $<21$ & & $0 / 8$ \\
\hline 4-Nonylphenol & $<18$ & & $0 / 4$ & $<18$ & & $0 / 6$ & $<18$ & & $0 / 8$ & $<18$ & & $0 / 8$ \\
\hline Diethylphthalate & $<33$ & & $0 / 4$ & $<33$ & & $0 / 6$ & $<33$ & & $0 / 8$ & $<33$ & & $0 / 8$ \\
\hline Dibutylphthalate & $6,425 \pm 4,146$ & $(2,600-10,400)$ & $4 / 4$ & $2,190 \pm 6,980$ & $(13,100-33,100)$ & $6 / 6$ & $5,067 \pm 2,344$ & $(1,300-7,700)$ & $8 / 8$ & $2,988 \pm 881$ & $(1,800-4,300)$ & $6 / 8$ \\
\hline
\end{tabular}

$*_{\mathrm{x}} / \mathrm{n}, \mathrm{x}=$ number of samples in which the contaminant concentration is higher than LOD, $\mathrm{n}=$ number of samples analyzed. 
The presence of this compound is directly related to the discharge of sewerage into the watershed. ${ }^{37}$ This contaminant was found in all the sampling spots throughout the whole year of study, with the highest concentrations found during the dry period ( $2^{\text {nd }}$ and $3^{\text {rd }}$ sampling), especially in Anhumas Creek. This water body is characterized by receiving high loads of untreated sewage as it flows through a densely urbanized district, being responsible for the largest punctual organic load into the Atibaia River. In this work, the concentration of caffeine increased markedly along of the course of Atibaia River, decreasing towards Salto Grande Dam (P7and P8 points). For example, in the $3^{\text {rd }}$ campaign, the concentrations of caffeine in Atibaia River was 3,300 $\mathrm{ng} \mathrm{L}^{-1}$ in Atibaia City (P1 site), 3,800 ng L ${ }^{-1}$ in Campinas (P2 site) before the entrance of the Pinheiros Creek.Then, the concentrations incresed to 5,500 $\mathrm{ng} \mathrm{L}^{-1}$ in P4 site, to reach $16,900 \mathrm{ng} \mathrm{L}^{-1}$ in P6 point, located in Paulínia.

During the four sampling campaigns, the pharmaceuticals (acetylsalicylic acid, acetaminophen, diclofenac and ibuprofen) were not detected at the 6 sampling points on the Atibaia River. However, in both the Anhumas and the Pinheiros Creek, three pharmaceutical compounds were detected at least once.

Acetylsalicylic acid (AAS) was detected in the Anhumas Creek in all campaigns, and the concentration varied inversely with the increase of the rain volume. In two campaigns performed during the dry period, AAS concentration was $20,960 \mathrm{ng} \mathrm{L}^{-1}$ in the second sampling and $12,212 \mathrm{ng} \mathrm{L}^{-1}$ in the third sampling campaign. As the river flow increased, the concentration of AAS decreased to 476 and $619 \mathrm{ng} \mathrm{L}^{-1}$. In the Pinheiros Creek, during the wet period, AAS concentration was $1,036 \mathrm{ng} \mathrm{L}^{-1}$. Considering the short residence time of this compound in the aquatic system, it is plausible to assume that this watershed is receiving a constant input of this compound along its course, whose major source is untreated sewage.

Acetaminophen was found in the dry periods in the Anhumas Creek in concentrations of 13,440 and $280 \mathrm{ng} \mathrm{L}^{-1}$, during the second and third sampling, respectively. These values are higher than the mean values detected in wastewater treatment plants in USA $\left.\left(1,780 \mathrm{ng} \mathrm{L}^{-1}\right)\right)^{38}$ England (4,174 $\left.\mathrm{ng} \mathrm{L}^{-1}\right)^{39}$ and Germany $\left(6,000 \mathrm{ng} \mathrm{L}^{-1}\right) .^{40}$ Kolpin et al. ${ }^{41}$ analyzed about 84 streams samples in the USA and determined acetaminophen in $24 \%$ of them, being $110 \mathrm{ng} \mathrm{L}^{-1}$ the median detectable concentration.

Diclofenac was detected in both the Anhumas and Pinheiros Creek during the fourth sampling in concentrations of 96 and $115 \mathrm{ng} \mathrm{L}^{-1}$, respectively. In terms of comparison, a pioneer work carried out in 1997 in the Paraíba River, in Rio de Janeiro State, the authors monitored
11 pharmaceuticals, and diclofenac concentrations varied between 10 and $60 \mathrm{ng} \mathrm{L}^{-1} .{ }^{42}$ As expected, ibuprofen, with a LOD of $51 \mathrm{ng} \mathrm{L}^{-1}$ and a limited use in Brazil, was not detected in any sample investigated in this work. The median ibuprofen concentration determined in Greifensee River (Switzerland) was $5 \mathrm{ng} \mathrm{L}^{-1}, 43597 \mathrm{ng} \mathrm{L}^{-1}$ in the Tyne River (England) ${ }^{42}$ and $3.5 \mathrm{ng} \mathrm{L}^{-1}$ in rivers of Finland. ${ }^{44}$

Considering the 26 samples collected at the eight sampling stations during the four campaigns, endocrine disruptor compounds were found in $92 \%$ of the samples. Among them, eight (dibutylphthalate, bisphenol A, $17 \beta$-estradiol, 17 $\beta$-ethynylestradiol, progesterone and levonorgestrel) were detected at least once. Dibutylphthalate, bisphenol A and 17 $\beta$-estradiol were found in all the campaigns. Dibutylphthalate was found with the highest frequency, $92 \%$, followed by bisphenol A, which appeared in $56 \%$ of the samples. The hormone $17 \beta$-estradiol was found in $35 \%$ of the samples. The synthetic hormone $17 \alpha$-ethynylestradiol was quantified in 3 of the 26 analyzed samples. Progesterone and levonorgestrel were found only in the fourth sampling campaign in concentrations of 195 and $663 \mathrm{ng} \mathrm{L}^{-1}$, respectively.

Estrone, 4-octylphenol, 4-nonylphenol and diethylphthalate had the lowest detection limit of the proposed method, i.e. $16,21,18$ and $33 \mathrm{ng} \mathrm{L}^{-1}$, respectively. The concentration of the four most frequently found compounds, including caffeine, are shown in Figure 6.

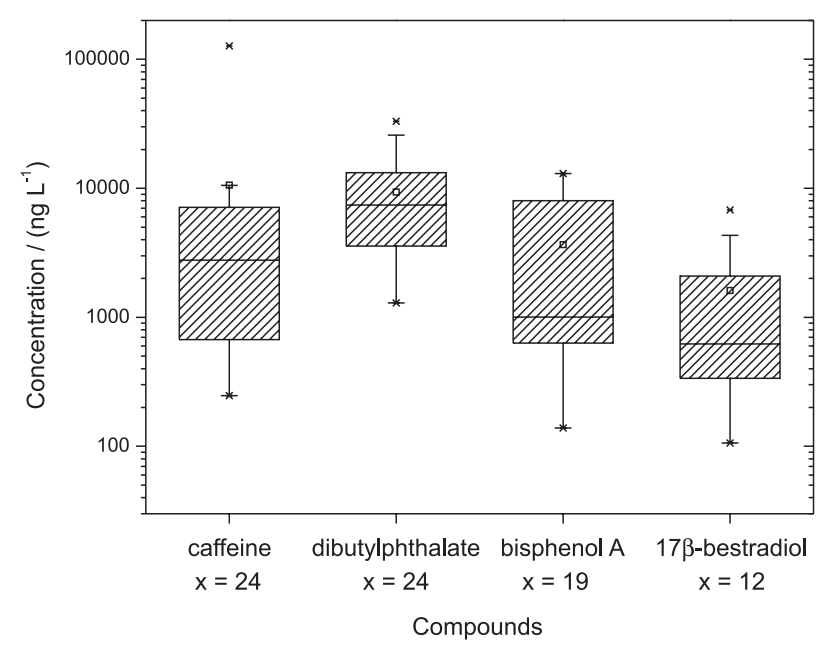

Figure 6. Concentrations of the four most frequently found compounds in the Atibaia watershed. The arithmetic means are represented by the square. Horizontal lines in the boxes represent 25, 50 (median) and 75\% of the values, error bars indicate 5 and $95 \%, \mathrm{X}$ values are maximum and minimum and $x$ values indicate the number of the samples in which the contaminant was detected in a total of 26.

Despite the fact that the concentrations of some compounds varied up to 6 orders of magnitude, the lowest variability was obtained for dibutylphthalate, showing 
mean and median concentrations of 9,342 and 7,414 $\mathrm{ng} \mathrm{L}^{-1}$, respectively. This compound was shown to be the least influenced by the seasonal hydrological cycle. Bisphenol A concentration varied from 204 to $13,016 \mathrm{ng} \mathrm{L}^{-1}$ and $17 \beta$-estradiol ranged from 106 to $6,806 \mathrm{ng} \mathrm{L}^{-1}$. For caffeine, levels varied between 174 and 127,092 $\mathrm{ng} \mathrm{L}^{-1}$. The highest concentrations of the selected compounds were determined in the dry season.

Assessing the spatial variation of caffeine and endocrine disruptors in the river Atibaia, there was an increase in the number of compounds and their concentration downstream in Campinas. In P1 and P2 points, two compounds were determined, caffeine and dibutylphthalate. In P4 point, another two compounds were determined, bisphenol $\mathrm{A}$ and $17 \beta$-estradiol beyond the caffeine and dibutylphthalate. In P6 site, the concentrations of the four compounds increased significantly. In P7 and P8 points due to Salto Grande Dam, only caffeine and dibutylphthalate were determined and the concentrations were similar to those found in P1 and $\mathrm{P} 2$ sites.

\section{Conclusions}

A single run optimization chromatographic method for the determination of 15 compounds present at trace levels in surface waters using SPE and HPLC-DAD-FLD was developed in this work. The performance of the method exhibits excellent linearity for all compounds $\left(r^{2}>0.996\right)$, satisfactory detectability, precision (CV $>5 \%$ for 12 of the compounds) and recoveries between 50 to $120 \%$ with synthetic samples. LOD values varied between 38 and $170 \mathrm{ng} \mathrm{L}^{-1}$, showing the efficiency of the method to determine these emerging contaminants in complex aqueous samples.

This work contributes to a better understanding of the scenario concerning the presence of emerging contaminants in Brazilian surface waters, as it provides a reliable tool to perform the chemical analysis of numerous compounds in a relatively simple chromatographic procedure. The analytical method employing SPE-HPLC-DAD-FLD was found to be efficient in the determination of the fifteen compounds at the nanogram per liter level with high sensitivity and detectability.

Among the pharmaceuticals investigated, acetylsalicylic acid was present in 5 among 26 analyzed samples, acetaminophen and diclofenac were detected in two samples and ibuprofen was not found in any of the samples. Caffeine, which was used as a tracer for anthropogenic activity, was found in all 8 sampling sites, confirming the fact that it can be used as a reliable tracer for the presence of other compounds.
Among the endocrine disruptors, dibutylphthalate was the compound present in most samples, followed by bisphenol $\mathrm{A}$ and the hormones, $17 \beta$-estradiol and $17 \alpha$-ethynylestradiol.

The highest concentrations of these compounds were observed in the dry season. The number of the contaminants increased along of the Atibaia River, predominantly downstream of Campinas City, as the concentrations decrease towards the Salto Grande Dam, where the Piracicaba River is formed. Both the Anhumas and the Pinheiros Creek were the ones mainly responsable for the inputs of the selected contaminants found in the Atibaia River.

\section{References}

1. International Programme on Chemical Safety, WHO, International Chemical Safety Cards, 2006, http://www.who. int/ipcs/publications/icsc/en/ accessed in May 2010.

2. Herman-Giddens, M. E.; Slora, E. J.; Wasserman, R. C.; Bourdony, C. J.; Bhapkar, M. V.; Koch, G. G.; Hasemeier, C. M.; Pediatrics 1997, 99, 505.

3. Tanner, J. M.; Nature 1973, 243, 95.

4. Sharpe, R. M.; Skakkebaek, N. E.; Lancet. 1993, 341, 1392.

5. Wolff, M. S.; Toniolo, P.; Lee, E.; Rivera, M.; Dubin, N.; J. Natl. Cancer Inst. 1993, 85, 648.

6. European Commission (EC) Environment, Water Framework Directive, Priority Substances and Certain Other Pollutants (According to Annex II of the Directive 2008/105/EC), 2006, http://ec.europa.eu/environment/water/water-framework/ priority_substances.htm accessed in August 2009.

7. The United States Food and Drug Administration (US-FDA), Bisphenol A (BPA), Update on Bisphenol A (BPA) for Use in Food: January 2010, http://www.fda.gov/newsevents/ publichealthfocus/ucm064437.htm accessed in January 2010.

8. Chen, P.; Pavelic, P.; Dillon, P.; Naidu, R.; Water Res. 2002, 36, 4830.

9. Broséus, R.; Vincent, S.; Aboulfadl, K.; Daneshvar, A.; Sauvé, S.; Barbeau, B.; Prévost, M.; Water Res. 2009, 43, 4707.

10. Snyder, S. A.; Wert, E. C.; Rexing, D. J.; Zegers, R. E.; Drury, D. D.; Ozone: Sci. Eng. 2006, 28, 445.

11. Matamoros, V.; Arias, C.; Brix, H.; Bayona, J. M.; Water Res. 2009, 43, 55.

12. Stasinakis, A. S.; Gatidou, G.; Mamais, D.; Thomaidis, N. S.; Lekkas, T. D.; Water Res. 2008, 42, 1796.

13. Radjenović, J.; Petrović, M.; Ventura, F.; Barceló, D.; Water Res. 2008, 42, 3601.

14. Bing-zhi, D.; Lin, W.; Nai-yun, G.; Desalination 2008, 221, 312.

15. Stackelberg, P. E.; Gibs, J.; Furlong, E. T.; Meyer, M. T.; Zaugg, S. D.; Lippincott, R. L.; Sci. Total Environ. 2007, 377, 255. 
16. Vieno, N. M.; Harkki, H.; Tuhkanen, T.; Kronberg, L.; Environ. Sci. Technol. 2007, 41, 5077.

17. Instituto Brasileiro de Geografia e Estatística (IBGE), Pesquisa Nacional de Saneamento Básico - 2000, Rio de Janeiro, Brasil, 2002, p. 397, http://www.ibge.gov.br/home/estatistica/ populacao/condicaodevida/pnsb/pnsb.pdf accessed in May 2009.

18. Rodil, R.; Quintana, J. B.; Mahía, P. L.; Lorenzo, S. M.; Rodríguez, D. P.; J. Chromatogr., A 2009, 1216, 2958.

19. The Merck index (CD ROM), version 12:2, Chapman \& Hall: New York, 1999.

20. Carballa, M.; Omil, F.; Lema, J. M.; Water Res. 2005, 39, 4790.

21. Katsu, T.; Tsunamoto, Y.; Hanioka, N.; Komagoe, K.; Masuda, K.; Narimatsu, S.; Anal. Chim. Acta 2008, 620, 50.

22. Huber, M. M.; Canonica, S.; Park, G. -Y.; von Gunten, U.; Environ. Sci. Technol. 2003, 37, 1016.

23. Verliefde, A.; Cornelissen, E.; Amy, G.; Bruggen, B. V.; Dijk, H.; Environ. Pollut. (Oxford, U. K.) 2007, 146, 281.

24. Christensen, F. M.; Regul. Toxicol. Pharmacol. 1998, 28, 212.

25. Fatoki, O. S.; Noma, A.; Water, Air, Soil Pollut. 2002, 140, 85.

26. Liu, Z.; Kanjo, Y.; Mizutani, S.; Sci. Total Environ. 2009, 407, 4975.

27. Baugros, J. B.; Giroud, B.; Dessalces, G.; Grenier-Loustalot, M. F.; Cren-Olive, C.; Anal. Chim. Acta 2008, 607, 191.

28. Centro de Pesquisas Meteorologicas e Climáticas Aplicadas a Agricultura (CEPAGRI - UNICAMP), http://www.cpa. unicamp.br/ accessed in January 2010.

29. The U.S. Environmental Protect Agency, Method 1694 Pharmaceuticals and Personal Care Products in Water, Soil, Sediment, and Biosolids by HPLC/MS/MS, Washington DC, USA, 2007.

30. The U.S. Environmental Protect Agency, Method 1698 Steroids and Hormones in Water, Soil, Sediment, and Biosolids by HRGC/HRMS, Washington DC, USA, 2007.
31. Miller, J. C.; Miller, J. N.; Statistics and Chemometrics for Analytical Chemistry, $5^{\text {th }}$ ed., Pearson: London, 2005, ch. 5.

32. Alda, M. J. L.; Barceló, D.; J. Chromatogr., A 2000, 892, 391.

33. Alda, M. J. L.; Barceló, D.; J. Chromatogr., A 2001, 911, 203.

34. Alda, M. J. L.; Barceló, D.; J. Chromatogr., A 2001, 938, 145.

35. Santos, J. L.; Aparício, I.; Alonso, E.; Callejón, M.; Anal. Chim. Acta 2005, 550, 116.

36. Ribeiro, C.; Tiritan, M. E.; Rocha, E.; Rocha, M. J.; J. Liq. Chromatogr. Relat. Technol. 2007, 30, 2729.

37. Buerge, I. J.; Poiger, T.; Muller, M. D.; Buser, H. R.; Environ. Sci. Technol. 2003, 37, 691.

38. Glassmeyer, S. T.; Furlong, E. T.; Kolpin, D. W.; Cahill, J. D.; Zaugg, S. D.; Werner, S. L.; Meyer, M. T.; Kryak, D. D.; Environ. Sci. Technol. 2005, 39, 5157.

39. Hilton, M. J.; Thomas K. V.; J. Chromatogr., A 2003, 1015, 129.

40. Stumpf, M.; Ternes, T. A.; Wilken, R. D.; Rodrigues, S. V.; Baumann, W.; Sci. Total Environ. 1999, 225, 135.

41. Kolpin, D. W.; Furlong, E. T.; Meyer, M. T.; Thurman, E. M.; Zaugg, S. D.; Barber, L. B.; Buxton, H. T.; Environ. Sci. Technol. 2002, 36, 1202.

42. Roberts, P. H.; Thomas K. V.; Sci. Total Environ. 2006, 356, 146.

43. Marin, A.; Espada, A.; Vidal, P.; Barbas C.; Anal. Chem. 2005, $77,471$.

44. Lindqvist, N.; Tuhkanen, T.; Kronberg L.; Water Res. 2005, 39, 2219.

Submitted: September 29, 2010

Published online: April 12, 2011

FAPESP has sponsored the publication of this article. 